Volume 10, Issue 6, November-December 2019, pp. 239-246, Article ID: IJM_10_06_023

Available online at http://iaeme.com/Home/issue/IJM?Volume $=10 \&$ Issue $=6$

Journal Impact Factor (2019): 9.6780 (Calculated by GISI) www.jifactor.com

ISSN Print: 0976-6502 and ISSN Online: 0976-6510

C IAEME Publication

\title{
FINANCIAL PERFORMANCE ANALYSIS OF PUMA
}

\author{
Dr. V. Andal \\ Associate Professor, Department of Commerce, VELS Institute of Science, \\ Technology and Advanced Studies, Chennai, Tamilnadu, India \\ Dr. S. Suganya \\ Assistant Professor, Department of Commerce, VELS Institute of Science, \\ Technology and Advanced Studies, Chennai, Tamilnadu, India

\section{Dr. S. Vennilaa Shree} \\ Professor, Department of Commerce, VELS Institute of Science, \\ Technology and Advanced Studies, Chennai, Tamilnadu, India
}

\begin{abstract}
The financial statement of PUMA, a sports company has been selected for this research. The financial statement has been examined throughout this paper. The financial statement includes the Income statement, Balance sheet, and Cash flow statement. Horizontal analysis, Vertical analysis, Trend analysis and mainly Ratio Analysis has been used to examine the financial performance and to make suggestions to improve finance flow, improve dividend and to reduce liabilities of PUMA. The major analysis is based on the financial years 2017 and 2016 ending on the 31 st of December in each and every year. The latest financial performance of the company is being compared with the company's statements for the last five years starting 2013 for showing trends. On the basis of the analysis, suggestions have been made to improve the financial performance and market share of PUMA.

Keywords: Financial ratio, PUMA, Financial analysis, Performance, Ratio Analysis.

Cite this Article: Dr. V. Andal, Dr. S. Suganya, Dr. S. Vennilaa Shree, Financial Performance Analysis of Puma, International Journal of Management (IJM), 10 (6), 2019, pp. 239-246.

http://iaeme.com/Home/issue/IJM?Volume $=10 \&$ Issue $=6$
\end{abstract}

\section{INTRODUCTION}

\subsection{Purpose of the Report}

The paper has been prepared in a report form to show the analysis of the very famous organization known as PUMA, manufacturer of sports apparels and sports Equipment Company. The analysis has been made in all respects such as vertical and horizontal and important rations have been prepared to know the overall performance of the company. These 
analysis and ratios would help the company in taking steps for the financial effectiveness of future and growth and to improve the market share of the company.

\subsection{Background of the Organization}

Puma SE has been branded as Puma. It is a German multinational company which designs and produces athletic and casual footwear, apparels and accessories. Its headquarters are in Herzogenaurach, Bavaria, Germany. Puma is the $3^{\text {rd }}$ largest manufacturer of sportswear in the world. Puma was founded by Rudolf Dassler in 1948. Rudolf and his brother Adolf Dassler had jointly formed the company Dassler Brothers shoe factory. In 1948, the relationship of two brothers ruined and two separate sports entities were formed namely Adidas and Puma. Puma was a public company since 1986 and which was listed at the Frankfurt stock exchange. Puma SE has more than 13,000 employees around the world and it distributes its products to 120 countries and more. Puma offers products for Football, Basketball, Running, Golf, Training and Fitness, Motorsports and sport style. It had sponsored many great athletes namely Pele, Eusebio, Johan Cruyff, Diego Maradona, Lothar Matthus, Clyde Frazier, Joe Namath, Boris Becker, Jim Hines, Martina Navarathilova, Colin Jackson, Tommie Smith, Linford Christie, Heike Drechsler, and Michel Schumacher. In 2018 Puma announced its entry back into basketball after 20 years.

\section{FINANCIAL PERFORMANCE}

\subsection{Financial Statements}

The Financial statements are the name given to income statement which is nothing, but profit $\&$ loss $\mathrm{a} / \mathrm{c}$ and the position statement of an enterprise known as the Balance sheet. These statements show the financial position of the business in a systematic manner. The Income statement reveals the net result of the organization during an accounting period and the Balance sheet shows the position of a company on a particular date, usually at the end of a financial year.

One account is usually prepared in the case of large business houses known as Trading and Profit \& Loss account for knowing gross profit, operating profit, and net profit. On the contrary, in the case of small-sized business houses, this account is prepared in two parts namely Trading Account and Profit \& Loss Account. Trading account is prepared to know the gross profit of the business and Profit and Loss Account is prepared to find out the net profit of the business. The Balance sheet reveals the position of various assets and liabilities of an organization at a particular time.

The financial statements are prepared to ascertain whether the organization has earned adequate profit and to know whether the profits have increased or decreased in comparison with the previous years. This comparison will help the organization to take corrective steps in advance. The financial statement helps to analyze the capacity of the organization to repay its short- and long-term liabilities. The comparison of data of two or more years of an organization will give inputs for the future growth of the business house. Various stakeholders who are keen to know the financial statement of an organization such as external capital providers, shareholders, government departments, suppliers, existing and future potential investors, lenders, client, employees, creditors, employees, competitors, and stockbrokers.

This report has examined the financial reports of the PUMA group for the period ending December $31^{\text {st }}$ December 2017. The analysis is based on the Income statement, Balance sheet, and the financial ratios. 


\subsection{Horizontal Analysis}

Horizontal analysis is used in the Analysis of financial statement to compare historical data of various years to know the increase or decrease of performance of various periods. This can either use absolute comparisons of percentage comparisons in which the figures in each succeeding period are expressed as a percentage of the amount in the base year. The base year amount is kept as $100 \%$ and it is been compared with the current year figures. This is known as the base year analysis. This horizontal analysis of financial statements over different periods allows investors to see what is been driving a company's financial performance over a number of years and also identifying trends and growth patterns such a seasonality. Generally, the charges are calculated on the basis of dollar and percentage, which are calculated on the basis of the following formulas:
i. $\quad$ Change in Dollar $=$ Comparison year - Base year
ii. $\quad$ Change in Percentage $=\mathrm{x} 100$
Dollar change

Amount of the item in the base year

Table 1: Horizontal Analysis

\begin{tabular}{|c|c|c|c|}
\hline ITEM & $\begin{array}{c}\mathbf{2 0 1 7} \\
(€ \text { in million })\end{array}$ & $\begin{array}{c}\mathbf{2 0 1 6} \\
(\boldsymbol{€} \text { in million })\end{array}$ & $\begin{array}{c}\text { Change } \\
\mathbf{\%}\end{array}$ \\
\hline Net Sales & 4,135 & 3,626 & 14 \\
\hline Cost of Sales & 2,181 & 1,970 & 11 \\
\hline Gross Profit & 1,954 & 1,656 & 18 \\
\hline Operating Expenses & 1,710 & 1,528 & 12 \\
\hline Operating Profit & 244 & 128 & 91 \\
\hline Income before taxes & 231 & 119 & 94 \\
\hline Net Income & 136 & 62 & 119 \\
\hline
\end{tabular}

The Horizontal analysis of Financial statements of PUMA is been done for income statement in the financial years 2016 and 2017 above. In comparison with 2016, Net income has increased by $119 \%$ even though the net sales were increased only by $14 \%$. These table and chart show that even though there is an increase of cost of sales by $11 \%$ and operating expenses by $12 \%$, the increase of operating profit by $91 \%$ and increase in operating expense is only $12 \%$, the net income has increased by $119 \%$. From the above analysis, PUMA is running very efficiently and has shown tremendous growth in Net profit.

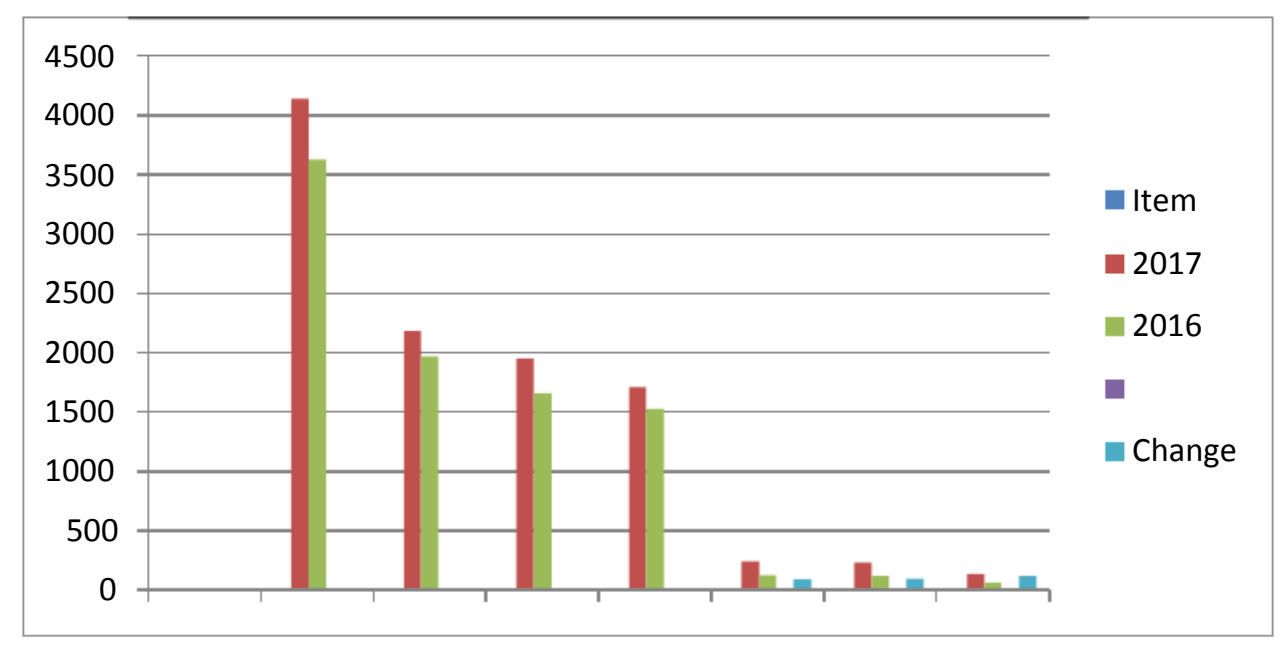

Figure 1: Horizontal Analysis 


\subsection{Trend Analysis}

Trend Analysis estimates an organization's financial position over a period of time. Depending on the circumstances, periods taken for this research may be measured in years, quarters or months. But the main goal is to calculate and analyze the change in absolute amount and change in percentage form from one period to the next.

Amount of modification $=$ Current year quantity - Base year quantity

Percent modification $=($ current year quantity - Base year quantity $) /$ Base year amount

Table 2 Trend Analysis

\begin{tabular}{|l|c|c|c|c|c|}
\hline & $\mathbf{2 0 1 3}$ & $\mathbf{2 0 1 4}$ & $\mathbf{2 0 1 5}$ & $\mathbf{2 0 1 6}$ & $\mathbf{2 0 1 7}$ \\
\hline Net Sales(€ million) & 2,985 & 2,972 & 3,387 & 3,627 & 4,136 \\
\hline & 100 & 99.6 & 113.5 & 121.5 & 138.6 \\
\hline Gross Profit (€ million) & 1,387 & 1,385 & 1,540 & 1,656 & 1,954 \\
\hline & 100 & 99.9 & 111 & 119.4 & 140.9 \\
\hline Operating Profit (€ million) & 63 & 128 & 96 & 128 & 244 \\
\hline & 100 & 203 & 152 & 203 & 387 \\
\hline Net Income (€ million) & 5 & 64 & 37 & 62 & 136 \\
\hline & 100 & 1280 & 740 & 1240 & 2720 \\
\hline
\end{tabular}

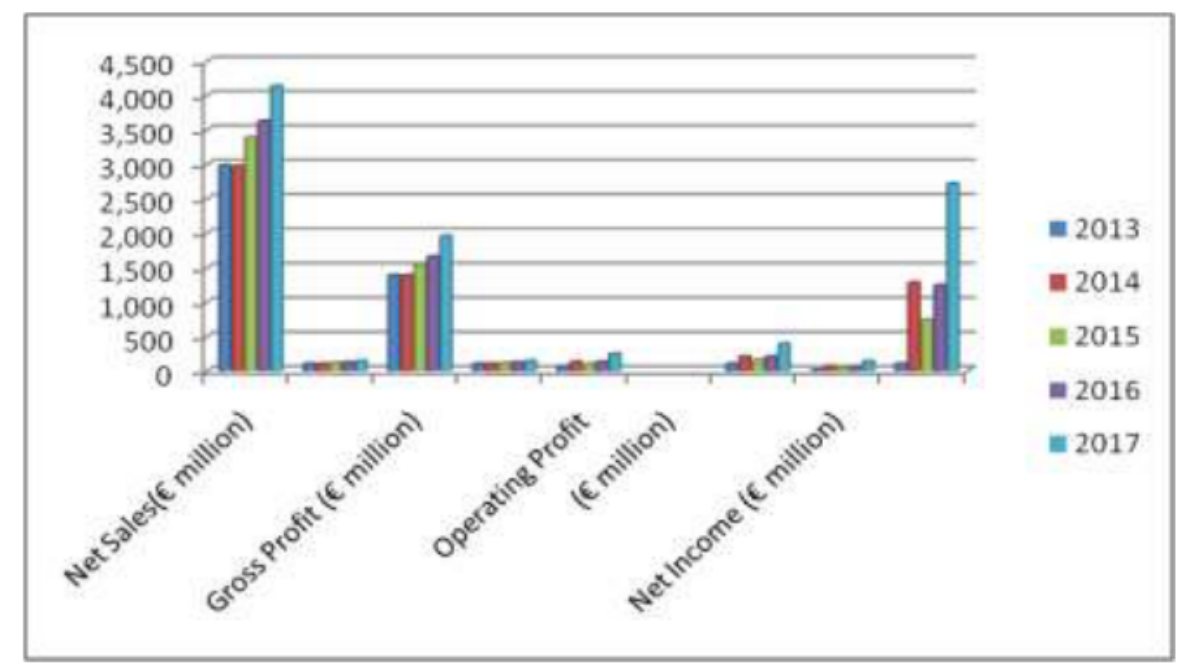

Figure 2 Trend Analysis

The above trend of income statement illustrates the analysis of the different period of net sales, gross profit and operating profit-taking 2013 as the base. While net sales of 2013 are compared with the net sales of 2014, it has reduced to some extent but afterward, it has gained momentum and there is a constant growth in net sales from 2015 till 2017. The Gross profit also shows the same trend as that of net sales. Unlike net sales and gross profit, the operating profit of 2014 has shown a tremendous rise of 203 when compared to 2013 but the operating profit has again reduced in the year 2015 by 152. Again in 2016, operating profit had touched the same profit of 2014 and it has shown a good increase in net profit in the year 2017. The net income of 2017 has shown a tremendous increase in the absolute value of $64 €$ million from $5 €$ million in the year 2013 because of the decrease in operating expenses in that year. The net financial gain is especially betting on operating expenses. Even though there is not much increase in net sales and gross profit, because of the decrease in operating expenses, the net profit is showing a constant increase in all the years till 2017. 


\subsection{Vertical Analysis}

Vertical analysis is the proportional analysis of a financial statement, in which each item of a financial statement is shown as a percentage of another item. Vertical analysis is useful for timeline analysis, to assess relative changes in accounts over time. While analyzing the vertical amounts on the balance sheet every amount on the balance sheet is restated to be a percentage of total assets. One of the main advantages of this analysis is that the balance sheet can be easily compared to any size of the organization and it will help to understand relative annual changes within one business.

Table 3 Vertical Analysis

\begin{tabular}{|l|c|c|c|c|}
\hline \multicolumn{1}{|c|}{ Assets } & $\begin{array}{c}\mathbf{2 0 1 7} \\
(\boldsymbol{€} \text { million })\end{array}$ & $\mathbf{\%}$ & $\begin{array}{c}\mathbf{2 0 1 6} \\
(\boldsymbol{€} \text { million })\end{array}$ & $\mathbf{\%}$ \\
\hline Cash and cash equivalents & 415 & 14.5 & 326.7 & 11.8 \\
\hline Account receivable & 503.7 & 17.7 & 499.2 & 18 \\
\hline Other current finance assets & 66.7 & 2.3 & 114.1 & 4 \\
\hline Inventories & 778.5 & 27.3 & 718.9 & 26 \\
\hline Income tax receivables & 26.8 & 0.9 & 37.4 & 1.4 \\
\hline Other current assets & 94.1 & 3.3 & 69.2 & 2.5 \\
\hline Non-current assets & 969 & 34 & 999.7 & 36.3 \\
\hline Total assets & $\mathbf{2 , 8 5 3 . 8}$ & $\mathbf{1 0 0}$ & $\mathbf{2 , 7 6 5 . 1}$ & $\mathbf{1 0 0}$ \\
\hline Liabilities and Equity & & & & \\
\hline Current Financial Liabilities & 29 & 1 & 25.3 & 0.9 \\
\hline Trade Liabilities & 646.1 & 22.6 & 580.6 & 21 \\
\hline Income taxes & 54.7 & 1.9 & 41.4 & 1.6 \\
\hline Other Current liabilities & 145.5 & 5.1 & 121.5 & 4.4 \\
\hline Other Current provisions & 86.2 & 3.1 & 56 & 2 \\
\hline Other current financial liabilities & 94.9 & 3.3 & 70 & 2.5 \\
\hline Total current liabilities & $\mathbf{1 , 0 5 6 . 5}$ & $\mathbf{3 7}$ & $\mathbf{8 9 4 . 8}$ & $\mathbf{3 2 . 4}$ \\
\hline Non-current liabilities & 140.7 & 4.9 & 148 & 5.4 \\
\hline Shareholder equity & $1,656.7$ & 58.1 & $1,722.3$ & 62.2 \\
\hline Total liabilities and equity & $\mathbf{2 , 8 5 3 . 8}$ & $\mathbf{1 0 0}$ & $\mathbf{2 , 7 6 5 . 1}$ & $\mathbf{1 0 0}$ \\
\hline
\end{tabular}

One of the main problems when exploiting vertical analysis for the record is what to use as the benchmark in the share calculation. The usual benchmarks are total asset taken as 100 and each line of asset is compared with total assets and in case of liabilities, total liabilities is taken as 100 and each line of the item in liabilities is compared with that and conclusion is arrived at.

The analysis shows that the total assets of the company increased from 2016 to 2017 and there is a decrease in other current financial assets and non-current assets. There is a constant increase in total current assets. PUMA has $59.17 \%$ higher the proportion of current assets in the situation to cover all current and non-current liabilities which is a total of $37 \%$. The company also has $14.5 \%$ of the cash and cash equivalents which can cover current financial liabilities, income tax, and other liabilities and provisions. The analysis shows that, PUMA strong working capital position and its ability to meet its near-term obligations.

\subsection{Financial Ratios}

A property organization needs effective planning and money management. Ratio analysis provides key indicators of organizational performance which is able to facilitate to grasp the organization money results and trends over time. The quantitative relation analysis reveals valuable data concerning organization's money attributes and it helps to match organization's quantitative relation with previous periods, challenger or trade average that will benefit to grasp the current business position of the organization. 
Summarizing quite advanced accounting details into a comparatively tiny number of key indicators is one of the main reasons to calculate a ratio. However, different users have different interests in money data which is able to confirm the ratios they have to use. For example, investors have an interest more in profitability ratios, liquidity ratios and solvency ratios. Therefore it is vital to spot the target of the finance report before calculating the ratios for generates useful knowledge.

\subsection{Key Ratios}

The ratios to be analyzed are credit payment period, return capital employed, current ratio, net profit margin and earnings per share. These ratios influence on the financial health of the company and vital for managers, stakeholders, investors, lenders, and suppliers. These ratios are a part of ratios such as liquidity ratios, productive ratios, profitability ratios investment ratios, and overall performance ratios.

Table 4: Key Ratios Analysis

\begin{tabular}{|l|c|c|c|}
\hline \multicolumn{1}{|c|}{ Item } & $\mathbf{2 0 1 7}$ & $\mathbf{2 0 1 6}$ & Change \% \\
\hline Creditor Payment Period & 108 days & 108 days & - \\
\hline Return on Capital Employed & $20.7 \%$ & $10.3 \%$ & 100.9 \\
\hline Current Ratio & $1.8: 1$ & $2: 1$ & -10 \\
\hline Interest Cover & 13.7 & 9.5 & 44.2 \\
\hline Earnings per share & $€ 9.09$ & $€ 4.17$ & 118 \\
\hline
\end{tabular}

Creditor payment period is a ratio of liquidity that indicates a company's capacity to pay off its account payable. The above ratio is used to judge the liquidity position of a business. This reveals that a number of times an organization can pay off its average accounts payable balance during the one financial year.

In 2016 and also in 2017, PUMA took 108 days to pay their traders. In general, organizations that need to maximize their cash flow have to take as long as possible to pay their bills. But 108 days is a far long time when compared with Nike which took just 24 days to pay off their bills in the 2017 financial year. There are several risks associated with taking more time than their agreement with the supplier such as loss of supplier goodwill and potential for late-payment charge and threat of legal actions.

Return on capital employed (ROCE) is a profitability ratio which indicates how efficiently an organization can generate profits from its capital employed by comparing profit before interest and tax to capital employed. This ratio calculation illustrates how much profit each Euro of employed capital generate; a higher number of ratios mean more Euros of profits generated by each Euros of capital employed.

The current ratio is a liquidity ratio which shows the proportion of current assets of a company in relation to its current liabilities. The calculation shows a company's ability to repay short-term liabilities. The ratio of 2:1 consider as the benchmark, however, it could vary across industries.

In 2016, PUMA has 2:1 in a current ratio which indicates sufficient money to meet current liabilities. This is the ideal current ratio. This shows that PUMA works efficiently. The company is financially strong enough to pay off its obligations. However, in 2017, PUMA's current ratio has reduced to $1.8: 1$. The ideal ratio has reduced to some extent. This may be due to the stiff competition that PUMA faces.

The interest cover ratio is computed on the basis of the company's ability to pay the interest on its outstanding debt. This helps to compute the number of times a company could pay its current interest payment with its available earnings. A company's capacity to meet its interest 
obligations is an aspect of a company's solvency as it is an important factor in the return for stakeholders. Therefore, the ratio is used to find out the lending funds risk to a company by lenders, creditors, and investors.

PUMA had 9.5 and 13.7 interest cover ratios in 2016 and 2017 respectively. In general, if the interests cover ratio shows a warning sign margin 2.5 , that company should be very careful about their upcoming financial situation. In this situation, PUMA is in sound financial health with confidence to pay their interest to lenders.

The earnings per share ratio indicate that the amount of a company's profit allocated each outstanding share of common stock. Indicating a high amount of earning per share ratio signals the potential of generating a significant dividend for investors. PUMA had $€ 4.17$ earnings per share in 2016 and it is increased to $€ 9.09$ in 2017. Somehow, PUMA shareholders can enjoy this high earnings per share in PUMA.

In summary, PUMA has a good financial position in 2016 when compared to the 2017 financial year. The company's earnings are good. The company has a good financial track to pay interest and earning per share is very good. The company had utilized its capital effectively so is in a good position when compared to its competitors.

\section{CONCLUSION}

The company is performing well, and it will continue to make profit and revenues for the next financial years. The operating profit is of PUMA is good. The company's return on capital employed in 2017 is more than doubled when compared to 2016. The company's net earnings are increasing every year. The company's interest cover ratio is good. The current ratio of PUMA has only reduced and in all other contexts, the financial position of PUMA has increased and strengthened. SO PUMA is utilizing all the resources such as financial, Human and energy.

\section{REFERENCES}

[1] https://en.wikipedia.org/wiki/Puma

[2] https://about.puma.com/en/investor-relations/financial-reports

[3] http://www.accountingnotes.net

[4] https://www.investopedia.com

[5] Dr. Veena K.P and Prof. S.N. Patti, Financial Performance Analysis of Pre and Post Merger in Banking Sector: A Study with Reference To ICICI Bank Ltd. International Journal of Management, 7(7), 2016, pp. 240-249.

[6] https://www.accountingformanagement.org/horizontal-analysis-of-financial-statements/

[7] https://saylordotorg.github.io/text_managerial-accounting/s17-01-trend-analysis-offinancial-st.html

[8] Sumi. KV, Financial Performance Analysis of Software Companies with special reference to Kerala. Journal of Management, 5(3), 2018, pp. 36-44

[9] https://www.accountingtools.com/articles/2017/5/17/vertical-analysis 


\section{APPENDIX}

\section{Calculation for Ratios}

\begin{tabular}{|c|c|c|}
\hline Current Ratio & Calculation & Ratios \\
\hline 2017 & $1884.8 / 1058.5$ & $1.8: 1$ \\
\hline 2016 & $1785.4 / 894.9$ & $2: 1$ \\
\hline Quick Assets Ratio & & 1 \\
\hline 2017 & $1106.3 / 1058.5$ & 1.17 \\
\hline 2016 & $1046.5 / 894.9$ & 5.5 \\
\hline Stock Turnover Ratio & & 5.3 \\
\hline 2017 & $4135.9 /(718.9+778.5) / 2$ & 125 days \\
\hline 2016 & $3626.7 /(718.9+657) / 2$ & 127 days \\
\hline Average time in Stock & & 108 days \\
\hline 2017 & $748.7 / 2181.5 \times 365$ & 108 days \\
\hline 2016 & $687.95 / 1970.3 \times 365$ & \\
\hline
\end{tabular}

